\title{
Influence of the predatory polychaete Nephtys hombergii on the abundance of other polychaetes
}

\author{
J. J. Beukema \\ Netherlands Institute for Sea Research, PO Box 59, 1790 AB Den Burg. Texel, The Netherlands
}

\begin{abstract}
Negative relations between abundance of the predatory polychaete Nephtys hombergii and values for biomass and rate of increase in 2 of its prey species, the polychaetes Scoloplos armiger and Heteromastus filiformis, are evident in long-term (18 yr) data from tidal flats in the westernmost part of the Wadden Sea. Values for prey biomass tended to decline at high $N$. hombergii biomass (above ca $0.3 \mathrm{~g} \mathrm{~m}^{-2}$ AFDW), whereas they tended to increase at lower levels of $N$. hombergii biomass. These results corroborate Schubert \& Reise's (Mar. Ecol. Prog. Ser. 34: 117-124, 1986) conclusion, based on short-term enclosure experiments, that $N$. hombergii is an important infaunal predator in the Wadden Sea.
\end{abstract}

\section{INTRODUCTION}

Both epifaunal and infaunal predators appear to affect the abundance of infaunal prey species in tidal flat sediments (Reise 1985). The role of epifaunal predators in structuring tidal flat ecosystems is well known, but the importance of infaunal predators has received little attention. Many polychaete species are potential predators of other endobenthic species (Commito \& Ambrose 1985), and some North American studies suggest that predatory polychaetes such as Nereis virens (Ambrose 1984, Commito \& Shrader 1985) and Glycera dibranchiata (Ambrose 1984) play a significant role in the structuring of marine sediment ecosystems. In the Wadden Sea, Schubert \& Reise (1986) showed convincingly that Nephtys hombergii Sav. consumed substantial numbers of some other species of endobenthic polychaetes, in particular the deposit-feeders Scoloplos armiger (O.F.M.) and Heteromastus filiformis (Clap.). Frequently, the densities of $N$. hombergii on tidal flats in the Wadden Sea (Beukema 1976, Beukema et al. 1978, Dankers \& Beukema 1983) should be sufficiently high to greatly reduce abundances of these prey species.

Results of the experiments by Schubert \& Reise (1986) were a stimulus to closely examine an extensive set of field data from the Wadden Sea. These data were gathered during an $18 \mathrm{yr}$ period of frequent sampling at 15 fixed stations on tidal flats in the westernmost part of the Wadden Sea. Abundances of Nephtys hombergii fluctuated greatly in this area as a consequence of its sensivity to low winter temperatures (Beukema 1979, 1984). Periods of high $N$. hombergii abundance alternated unpredictably with periods of scarcity (Beukema et al. 1978). If it is permissible to extrapolate the results of Schubert \& Reise (1986) from small enclosures over short periods to entire tidal flats over years, then significant differences may be expected in the responses of prey populations to the observed variations in $N$. hombergii abundance. The irregular reductions in the $N$. hombergii population by severe winters thereby provided large-scale natural experiments on the predatory effects of this species.

\section{MATERIALS AND METHODS}

The 15 sampling stations are scattered over the 50 $\mathrm{km}^{2}$ tidal flat area known as Balgzand (Fig. 1), which is located in the westernmost part of the Wadden Sea. Among these 15 stations, 3 are square plots of $900 \mathrm{~m}^{2}$ each and 12 are transects of $1 \mathrm{~km}$ each. All stations are marked by permanent iron poles.

These 15 stations have been sampled in a uniform way at least annually (in late winter/early spring, mostly in March) since 1969. The 3 square plots were sampled year-round, at least 4 times per year. Sampling procedures were described in detail by Beukema $(1974,1979)$. In short: cores were taken and sieved in the field on $1 \mathrm{~mm}$ mesh screens. All samples were 


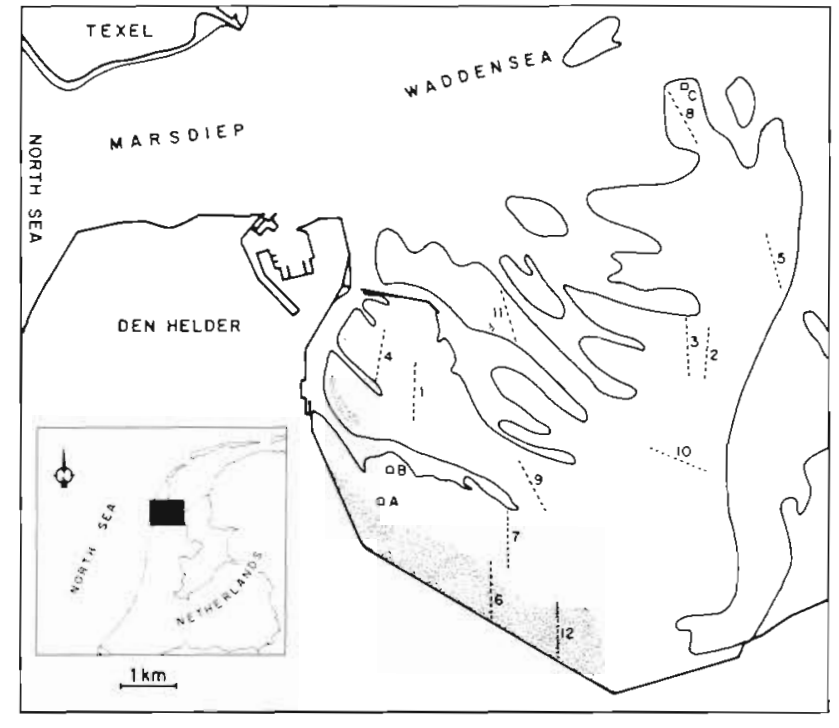

Fig. 1. Map of the Balgzand tidal flat area showing locations of sampling stations ( 3 square plots, 12 transects numbered 1 to 12)

sorted in the laboratory while the animals were still alive, thereby facilitating complete extraction of the worms from the sieve residues.

The total area sampled varied from 0.9 to $1.6 \mathrm{~m}^{2}$ per station among the sampling events. Abundances are expressed per $\mathrm{m}^{2}$, and biomass is given as $\mathrm{g} \mathrm{m}^{-2}$ AFDW (ash-free dry weight). In this study, biomass data are preferred over numerical abundance data for several reasons: (1) The quantities of prey consumed by Nephtys hombergii will be more closely related to the weights of this predator than to its numbers because the mean size of $N$. hombergii was highly variable; (2) In both predator and prey, the data on numerical abundance are less accurate than the biomass data because unknown quantities of the smallest sizeclasses of the worms escaped through the meshes of the sieve. These losses would have affected estimates of numerical abundance more seriously than biomass estimates because the smallest worms would contribute little to biomass but greatly to numbers; (3) Fragmented worms could be included unambiguously.

All types of tidal flats were represented among the sampling stations, from high to low water level and from soft muds to clean sands. The 3 aforementioned polychaete species are not found everywhere on these tidal flats. Each is restricted to specific ranges of intertidal levels and silt contents of the sediment (Dankers \& Beukema 1983). Nephtys hombergii and Scoloplos armiger avoid the higher and siltier areas, whereas Heteromastus filiformis is rare in the lowest and sandiest sediments (Dankers \& Beukema 1983: Fig. 23). Thus, a study of predator-prey relationships makes sense only for part of the sampled area. As criteria, firstly the initial abundance of the prey species was used (for each individual year and sampling station, it should exceed $0.1 \mathrm{~g} \mathrm{~m}^{-2}$ AFDW) and secondly the abundance of the predator (at each station, its biomass should exceed $0.3 \mathrm{~g} \mathrm{~m}^{-2}$ during at least part of the years). The southwestern coastal part of Balgzand is silty and high (mostly above Mean Tide Level, MTL: the shaded parts in Fig. 1). $S$. armiger biomass values were invariably below $0.1 \mathrm{~g} \mathrm{~m}^{-2}$ at Stns A, 4, 6, 7 and 12, and during several years also at Stns 1,5 and 9 . The exposed northeastern part of Balgzand is sandy and low with invariably low $H$. filiformis abundance at Stns $C, 5$ and 8 , and during several years also at Stns 2, 3 and 11. None of the data from Stns 6 and 12 were used because $N$. hombergii biomass was very low during all years at these high stations. As a result, data from 10 stations could be used for each of the relations Nephtys-Scoloplos and Nephtys-Heteromastus, yielding 121 and 135 data pairs, respectively.

Mean values are shown with one standard error. By way of precaution, only non-parametric tests were used for statistical comparisons because the data were often highly variable (with variances several times higher than the means, see Beukema et al. 1983) and nonnormally distributed. The following tests were used: (1) The Mann-Whitney U test (Siegel 1956) to compare the means of prey biomass values at high and low predator densities in the same season (Fig. 2 \& 4) and to compare the (weighted) means of the relative changes in prey biomass after 1 yr at high and low predator densities (Table 1). (2) The Friedman 2-way analysis of variance by ranks (Siegel 1956), as modified by De Jonge (1963) to allow for unequal distances, to evaluate annual trends in the changes of prey biomass at different predator abundance (Fig. 2 \& 4). (3) The Spearman rank correlation test (Siegel 1956) to measure the association between the predator abundance and the change of prey biomass (Fig. $3 \& 5$ ). All $\mathrm{r}$ values given are Spearman rank coefficients

\section{RESULTS}

\section{Response of Heteromastus filiformis to variation in Nephtys hombergii abundance}

At only one of the 3 frequently sampled square plots (Stn B, Fig. 1), were both Nephtys hombergii and Heteromastus filiformis sufficiently abundant during most years to compare the changes in $H$. filiformis biomass at different levels of $N$. hombergii abundance. During each of the 18 successive years (1969 to 1986) biomass estimates were obtained for each of 4 seasons: winter, early spring, early summer and late summer. The $18 \mathrm{yr}$ were divided into 2 nearly equally-sized 


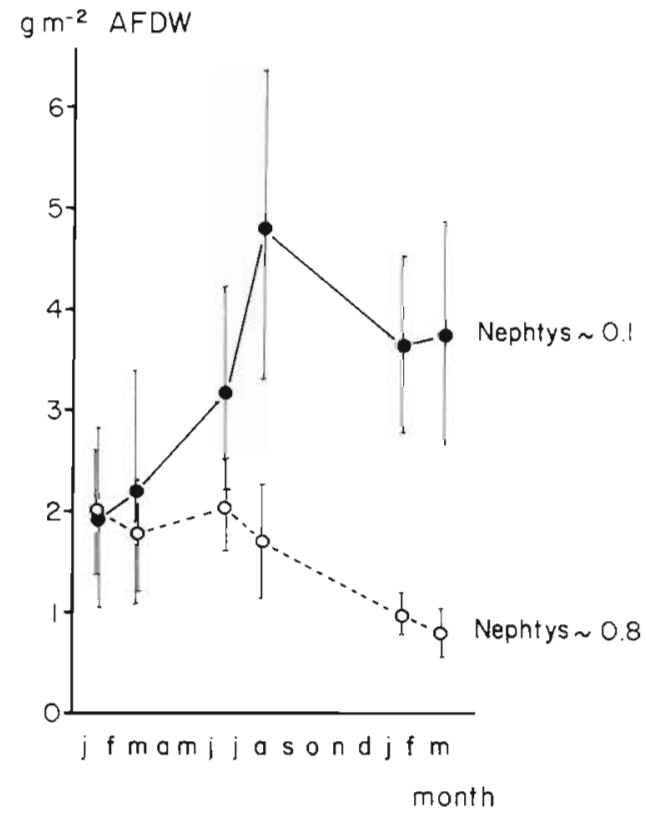

Fig. 2. Heteromastus filiformis. Annual course of mean biomass values $\left(\mathrm{g} \mathrm{m}^{-2}\right.$ AFDW, with 1 standard error) at the frequently sampled Stn B during years of low ( 8 yr) and high (10 yr) abundance of the predatory worm Nephtys hombergii

groups, with high and low predator abundance, respectively. During 10 yг $N$. hombergii biomass was judged high, i.e. between 0.4 and $1.4 \mathrm{~g} \mathrm{~m}^{-2}$ (mean $0.78 \pm$ $0.10)$, and during the other 8 yr low: between 0 and 0.4 $\mathrm{g} \mathrm{m}^{-2}$ (mean $0.14 \pm 0.04$ ). The biomass values for $H$. filiformis were averaged for these 2 groups of years separately (the values for the first few months of the next year were included to obtain the biomass change during a full year; see Fig. 2).

The Heteromastus filiformis biomass varied greatly from year to year, but fortunately mean values at the start of the year were nearly equal for the 2 groups of $(8$ and 10) years (viz. about $2 \mathrm{~g} \mathrm{~m}^{-2}$ : the 2 leftmost points in Fig. 2). However, subsequent changes in prey biomass were quite different between years with high and low Nephtys hombergii abundance (Fig. 2). At low predator abundance, biomass of the $H$. filiformis popu- lations increased significantly $(\mathrm{p}<0.01)$. H. filiformis populations declined at high $N$. hombergii abundance. After 1 yr of low $N$. hombergii densities, the mean abundance of $H$. filiformis nearly doubled and was significantly higher $(\mathrm{p}<0.05$, both for the winter and early-spring data) than the roughly halved $H$. filiformis biomass at high $N$. hombergii densities (Fig. 2: the 4 rightmost points). Mean winter and early-spring biomass values after 1 yr of low $N$. hombergii abundance were respectively 1.90 and 1.71 times higher than at the start of the year. These ratios were only 0.49 and 0.46 , respectively, at high $N$. hombergii abundance. The differences between these ratios at low and high predator abundance are significant at the 0.05 level (Table 1).

Relative changes in biomass such as doubling and halving after 1 yr can also be directly related to individual values of Nephtys hombergii abundance in each of the 18 separate years, and evidenced by a significantly negative correlation $(\mathrm{r}=-0.55$ for the winter data and -0.53 for the early-spring data, both $p<$ 0.05 ). Thus, the higher the biomass of the predator was during year $\mathrm{n}$, the lower the prey biomass was at the start of year $n+1$, compared to its abundance at the start of year $n$.

Even higher numbers of such annual ratios of change in prey biomass are available from the transects sampled in March. Including the 18 observations from the above square-plot station, a total of 135 pairs of data could be correlated. Instead of year-round data for Nephtys hombergii (which would yield a true annual average for predator biomass), only one seasonal estimate is available. However, this limitation is not serious because the values for $N$. hombergii biomass in March were well correlated ( $\mathrm{r}$ values around +0.8 ) with those in subsequent months up to, but not including, the following winter (as observed at the 2 frequently sampled square-plot stations, $B$ and $C$ ).

The ratios of annual change of Heteromastus filiformis biomass (i.e. biomass in March of year $\mathrm{n}+1$ divided by biomass in March of year $n$ ) declined with increasing values of Nephtys hombergii biomass in March of

Table 1. Heteromastus filiformis and Scoloplos armiger. Weighted means of relative annual changes in biomass of these prey species at high and low abundance of the predator Nephtys hombergii. In parentheses: no of observations (yr). $p<0.05$; - p $<0.01$

\begin{tabular}{|c|c|c|c|c|c|c|}
\hline \multirow[b]{2}{*}{$\begin{array}{l}\text { Nephtys biomass } \\
\qquad\left(\mathrm{g} \mathrm{m}^{-2}\right)\end{array}$} & \multicolumn{2}{|c|}{$\begin{array}{l}\text { Heteromastus filiformis } \\
\text { Stn B }\end{array}$} & \multicolumn{4}{|c|}{ Scoloplos armiger } \\
\hline & $\begin{array}{l}\text { High } \\
(0.78)\end{array}$ & $\begin{array}{l}\text { Low } \\
(0.14)\end{array}$ & $\begin{array}{l}\text { High } \\
(0.78)\end{array}$ & $\begin{array}{l}\text { Low } \\
(0.14)\end{array}$ & $\begin{array}{l}\text { High } \\
(0.55)\end{array}$ & $\begin{array}{c}\text { Low } \\
(0.22)\end{array}$ \\
\hline \multicolumn{7}{|c|}{ Prey changes (biomass year $n+1 /$ year $n$ ) } \\
\hline Winter-winter & $0.49(10)^{\circ}$ & $1.90(8)$ & $0.80(10)$ & $1.38(8)$ & $0.91 \quad(9)$ & $1.25(9)$ \\
\hline Spring-spring & $0.46(10)^{\circ}$ & $1.71(8)$ & $0.92(10)$ & $1.07(8)$ & $0.99(9)$ & $1.27 \quad(9)$ \\
\hline Combin-combin. & $0.47(20)^{\cdots}$ & $1.80(16)$ & $0.85(20)^{\cdots}$ & $1.19(16)$ & $0.97(18)^{\circ}$ & $1.26(18)$ \\
\hline
\end{tabular}




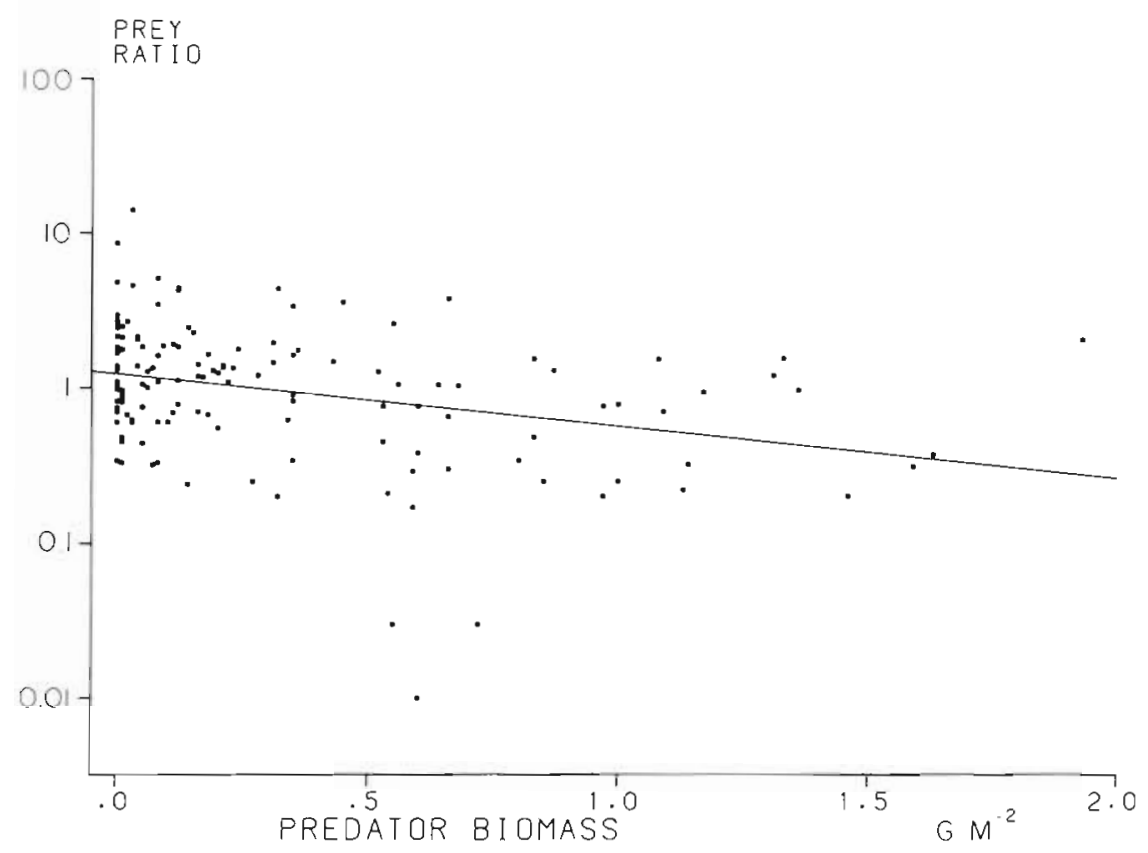

Fig. 3. Relation between abundance of the predatory worm Nephtys hombergii ( $\mathrm{g} \mathrm{m}^{-2}$ AFDW) at the start of the year and subsequent (relative) change in the biomass of its prey Heteromastus filiformis year $n$ (Fig. 3: $r=-0.32, p<0.001$ ). Thedata in Fig. 3 are plotted on a semi-logarithmic scale to show equal distances from equality for both doubling and halving of prey abundance. The best-fitting straight line is described by: log (ratio of annual change of Heteromastus $)=0.10-0.37$ (Nephtys biomass). This formula indicates that: (1) in the absence of $N$. hombergii, $H$. filiformis increases an average of about $25 \%$ per year (as 0.10 equals $\log 1.25$ ); (2) $H$. filiformis remains (on average) stable at an $N$. hombergii biomass of about 0.3 $\mathrm{g} \mathrm{m}^{-2}$ (as 0.10 divided by 0.37 equals about 0.3 ) : (3) $\mathrm{H}$. filiformis decreases (on average) at any biomass of $N$. hombergii higher than about $0.3 \mathrm{~g} \mathrm{~m}^{-2}$, and decreases faster at greater $N$. hombergii biomass. For instance, $H$. filiformis biomass roughly halves each year at $1 \mathrm{~g} \mathrm{~m}^{-2}$ of $N$. hombergii (as -0.27 equals $\log 0.54$ ).

\section{Response of Scoloplos armiger to variation in Nephtys hombergii abundance}

Changes in Scoloplos armiger biomass were analysed in a similar manner to those shown above for Heteromastus filiformis. Because the distributions of Nephtys hombergii and $S$ armiger overlap to a greater extent than those of $N$. hombergii and $H$. filiformis (Dankers \& Beukema 1983: Fig. 23), the available data allowed a detailed study on the relations between $N$. hombergii and $S$. armiger at 2 of the frequently sampled square-plot stations (B and C). For Stn B, the same division in years with high and low predator abundance was made as mentioned above for the NephtysHeteromastus relation. Stn $C$ was located at a low intertidal level where $N$. hombergii abundance varied Iittle (for reasons explained in Beukema 1984). its mean biomass during the group of 9 yr with relatively high densities was $0.55 \pm 0.05 \mathrm{~g} \mathrm{~m}^{-2}$, and its mean biomass during the 9 yr of low densities $0.22 \pm 0.03 \mathrm{~g} \mathrm{~m}^{-2}$.

The annual courses of Scoloplos armiger biomass were similar at the 2 stations (Fig. $4 \mathrm{a}$, b). Beginning with roughly the same biomass in winter and early spring, the biomass values for $S$. armiger appear to reach higher mean values during the months subsequent to low $N$. hombergii biomass than during the months subsequent to high $N$. hombergii biomass. Because of high year-to-year variability (already present at the start of the year), the differences are, however, statistically nonsignificant.

After 1 yr of low Nephtys hombergij biomass, Scoloplos armiger biomass increased by a mean of about $20 \%$, whereas it declined by a similar mean percentage at high $N$. hombergii biomass (Table 1). At each of the 2 stations, the differences between these ratios are statistically significant only for the combined January and March data (Table 1).

Direct correlations of the individual annual ratios of change in Scoloplos armiger biomass at the 2 squareplot stations with mean annual Nephtys hombergii biomass yielded negative correlations in all 4 cases ( 2 stations $\times 2$ months). Values of $r$ varied from -0.20 to -0.60 , but only one of those correlations was significant at $\mathrm{p}<0.05$ (the one for January data at Stn B).

By including the transect data, 121 pairs of data on Nephtys hombergii abundance versus ratio of annual change in Scoloplos armiger abundance were available. The resulting relation was again negative (Fig. 5: $r=-0.21, p<0.02$ ) with a best-fitting straight line described by log(ratio of annual change of Scoloplos) $=0.11-0.38$ (Nephtys biomass). This formula strongly 

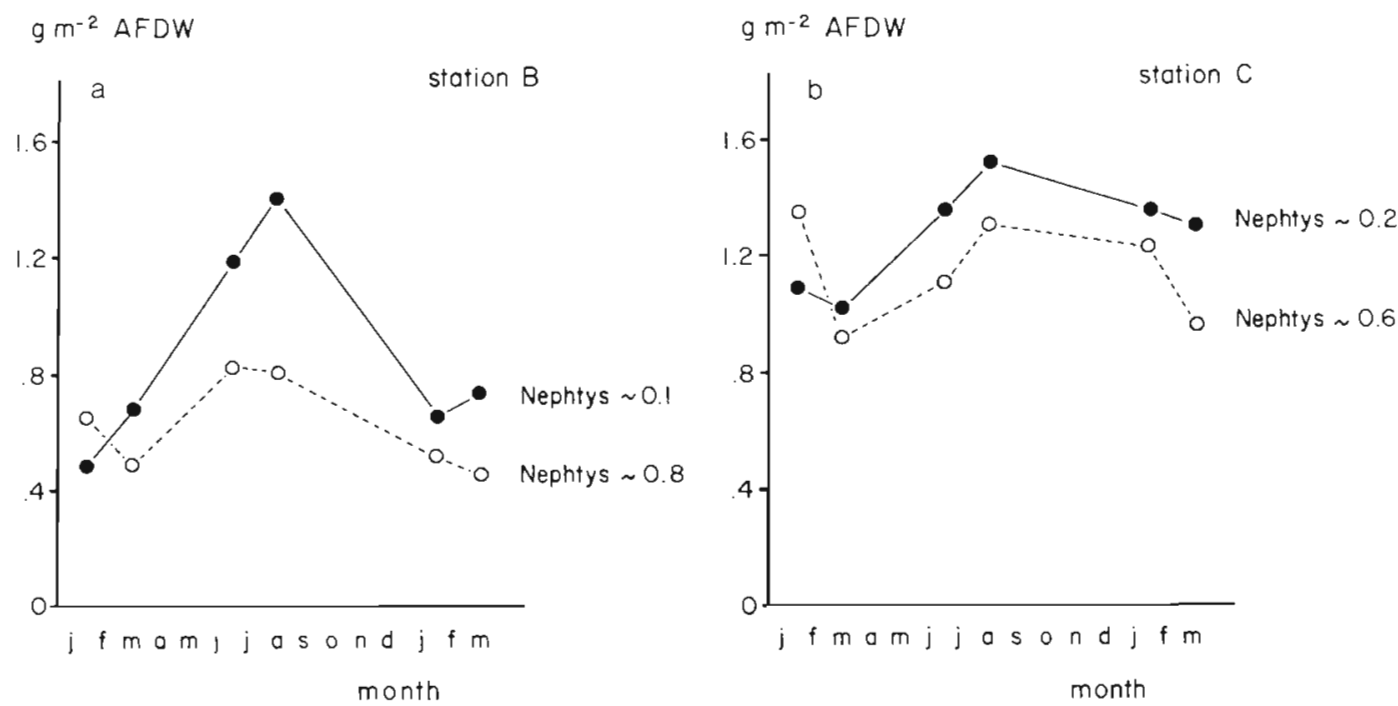

Fig. 4. Scoloplos armiger. Annual courses of mean biomass values $\left(\mathrm{g} \mathrm{m}^{-2}\right.$ AFDW $)$ at 2 frequently sampled stations during years of low and high abundance of the predatory worm Nephtys hombergii. (a) Stn B; (b) Stn C

resembles the one obtained for Heteromastus filiformis (see above) and is interpreted similarly.

\section{DISCUSSION}

From an analysis of gut contents of Nephtys hombergï collected at tidal flats near Sylt in the Wadden Sea, Schubert \& Reise (1986) concluded that the worms Scoloplos armiger and Heteromastis filiformus are major prey of this predatory polychaete. Some other worm species were also observed in the guts of $N$. hombergii, but only in small numbers. In enclosure experiments in the same area, they found consistent. substantial declines in the numbers of both $S$. armiger and $H$. filiformis in the presence of high densities of $N$. hombergii, while densities of other endozoobenthic species were not consistently affected. Though the predator densities in these enclosure experiments were unrealistically high

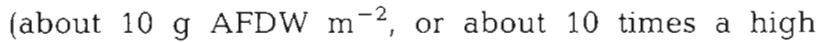
natural density of $N$. hombergii on tidal flats of the Wadden Sea), a rough estimate could be made of predation rates at natural densities for entire years. Schubert \& Reise estimated an annual consumption per medium-sized $N$. hombergii (about $70 \mathrm{mg}$ AFDW) of 300 to $700 \mathrm{mg}$ of worms (or roughly 4 to 10 times their own weight).
Fig. 5. Relation between abundance of the predatory worm Nephtys hombergii ( $\mathrm{g} \mathrm{m}^{-2}$ AFDW) at the start of the year and subsequent (relative) change in the biomass of Scoloplos armiger

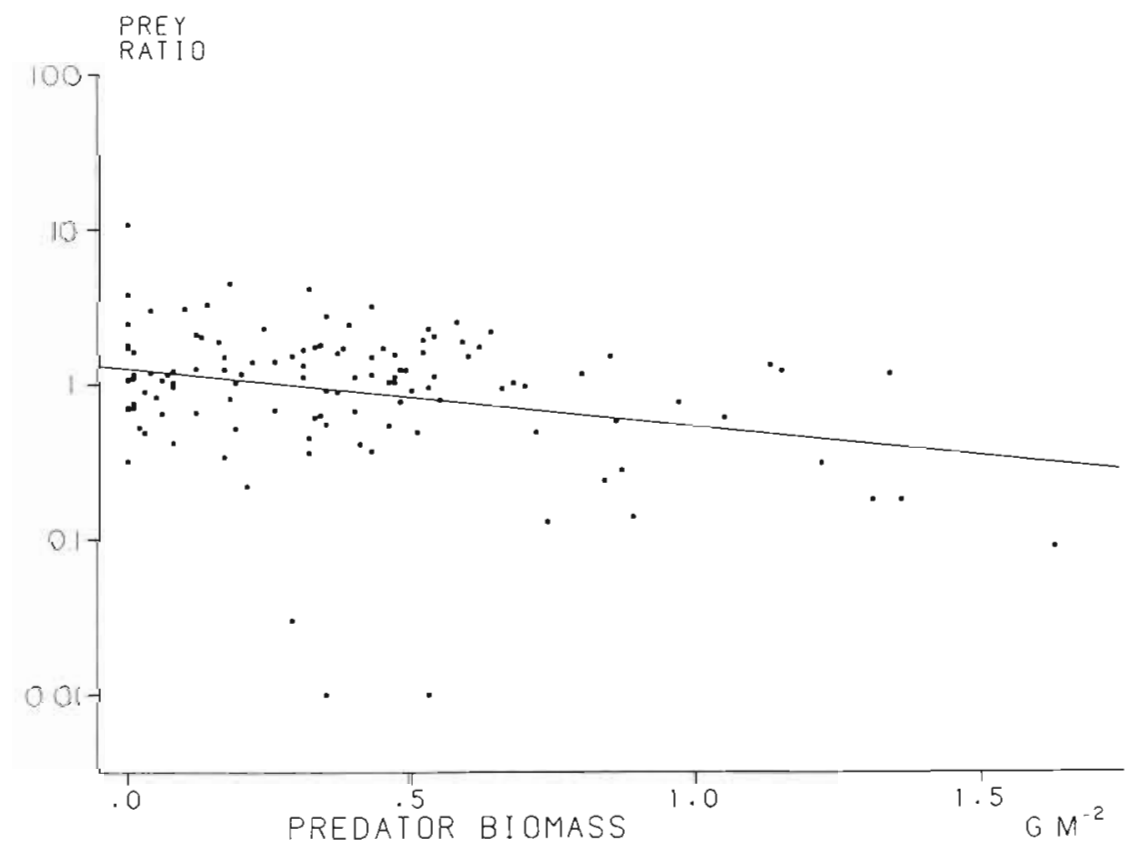


The data gathered on Balgzand (a tidal flat area with a very similar ecosystem) and presented above offered an opportunity to test the foregoing extrapolations from small-scale, short-term experiments. In the case of the square-plot sampling station, B (Fig. 2 \& 4a), the difference between mean Nephtys hombergii biomass during years with high and low abundance amounted to $0.78-0.14=0.64 \mathrm{~g} \mathrm{~m}^{-2}$. By the calculations of Schubert \& Reise (1986), such an amount of extra $N$. hombergii biomass would consume annually between 2.7 and $6.4 \mathrm{~g} \mathrm{~m}^{-2}$ of prey worms (i.e. 4 to 10 times their own weight). The actual mean difference in biomass of prey worms observed at the end of the year at Stn B was $2.7 \mathrm{~g} \mathrm{~m}^{-2}$ of Heteromastus filiformis $+0.1 \mathrm{~g} \mathrm{~m}^{-2}$ of Scoloplos armiger $=2.8 \mathrm{~g} \mathrm{~m}^{-2}$ for the January data and $3.0+0.3=3.3 \mathrm{~g} \mathrm{~m}^{-2}$ of prey worms for the March data. Due almost exclusively to the strong reduction in the biomass of $H$. filiformis (Fig. 2), these figures are within the lower end of the range expected based on estimates by Schubert \& Reise.

At Stn C (Fig, 4b), the difference in Nephtys hombergii biomass between the groups of years with high and low predator abundance was $0.55-0.22=0.33 \mathrm{~g} \mathrm{~m}^{-2}$, with an expected consumption of between 1.4 and $3.3 \mathrm{~g}$ $\mathrm{m}^{-2}$. Almost no Heteromastus filiformis occurred at this sandy station. The reduction in Scoloplos armiger biomass (Fig. 4b) amounted to only about one tenth of the foregoing estimate of $N$. hombergii consumption.

Thus, at both stations Scoloplos armiger appears to be reduced to a much lesser extent than would be expected from the Schubert \& Reise estimates, whereas Heteromastus filiformis did show the expected reduction in biomass. This difference in response between the prey species could easily arise from the different ways in which Nephtys hombergii attacks these species. In a laboratory feeding experiment, Schubert $\&$ Reise (1986) observed that $N$. hombergii swallowed $H$. filiformis whole, but ate only tail ends of $S$. armiger. The latter thus remained alive and regenerated their tail ends. Cropping regenerating tail ends would only slightly reduce biomass compared with the destruction of entire worms. As in the case of tails of lugworms cropped by plaice (Beukema \& de Vlas 1979, de Vlas 1979), production by such prey populations is actually much higher than estimates from dynamics of numbers would suggest. Thus, $N$. hombergii might have consumed much higher amounts of $S$ armiger than the reduction in biomass in this prey would suggest.

The second set of data presented (mainly transect data) indicates that Nephtys hombergii effectively regulates abundances of the 2 prey species (Figs. $3 \& 5$ ). The prey populations tend to decline at high predator abundance (i.e. above $0.3 \mathrm{~g} \mathrm{~m}^{-2}$ ) and tend to increase at lower predator densities. This crucial density of $0.3 \mathrm{~g}$ $\mathrm{m}^{-2}$ of $N$. hombergii equals the mean density observed during a separate large-scale survey (99 transects) of tidal flat fauna from the Dutch Wadden Sea (Beukema 1976).

Fig. $3 \& 5$ show a high scatter of individual data. Thus, no conclusion can be drawn about the possible shape of a best-fitting curve and no special meaning should be attached to the straight lines drawn. The only conclusion in this matter that appears to be warranted is that the relations between predator abundance and rate of change of prey biomass are negative for both prey species. The high scatter indicates that other environmental factors also affect abundances of Heteromastus filiformis and Scoloplos armiger. However, Nephtys hombergii appears to be an important predator that controls, in part, abundances of 2 infaunal polychaetes on tidal flats in the Wadden Sea.

\section{LITERATURE CITED}

Ambrose, W. G. (1984). Influences of predatory polychaetes and epibenthic predators on the structure of a soft-bottom community in a Maine estuary. J. exp. mar. Biol. Ecol. 81: $115-145$

Beukema, J. J. (1974). Seasonal changes in the biomass of the macro-benthos of a tidal flat area in the Dutch Wadden Sea. Neth. J. Sea Res. 8: 94-107

Beukema, J. J. (1976). Biomass and species richness of the macro-benthic animals living on the tidal flats of the Dutch Wadden Sea. Neth. J. Sea Res. 10: 236-261

Beukema, J. J. (1979). Biomass and species richness of the macrobenthic animals living on a tidal flat area in the Dutch. Wadden Sea: effects of a severe winter. Neth. J. Sea Res. 13: 203-223

Beukema, J. J. (1984). Zoobenthos survival during severe winters on high and low tidal flats in the Dutch Wadden Sea. In: Gray, J. S., Christiansen, M. E. (ed.) Marine biology of polar regions and effects of stress on marine organisms. Wiley, London, 351-361

Beukema, J. J., de Vlas, J. (1979). Population parameters of the Lugworm, Arenicola marina, living on tidal flats in the Dutch Wadden Sea. Neth. J. Sea Res. 13: 331-353

Beukema, J. J., de Bruin, W., Jansen J. J. M. (1978). Biomass and species richness of the macrobenthic animals living on the tidal flats of the Dutch Wadden Sea: long-term changes during a period with mild winters. Neth. J. Sea Res. 12: 58-77

Beukema, J. J., Cadée, G. C., Hummel, H. (1983). Differential variability in time and space of numbers in suspension and deposit feeding benthic species in a tidal flat area. Oceanologica Acta No. Sp.: 21-26

Commito, J. A.. Ambrose, W. G. (1985). Multiple trophic levels in softbottom communities. Mar Ecol. Prog. Ser. 26: 289-293

Commito, J. A., Shrader, P. B. (1985). Benthic community response to experimental additions of the polychaete Nereis virens. Mar. Biol. 86: 101-107

Dankers, N., Beukema, J. J. (1983). Distributional patterns of macrozoobenthic species in relation to some environmental factors. In: Wolff, W. J. (ed.) Ecology of the Wadden Sea I. Balkema, Rotterdam, p. 69-103

Jonge, $H$ de (1963). Inleiding tot de medische statistiek. Deel 1 Verh. Ned. Inst. Praevent. Geneesk. 41:1-421 
Reise, K. (1985). Tidal flat ecology. Springer-Verlag, Heidelberg

Schubert, A., Reise, K. (1986). Predatory effects of Nephtys hombergii on other polychaetes in tidal flat sediments. Mar. Ecol. Prog. Ser. 34: 117-124
Siegel, S. (1956). Nonparametric statistics for the behavioral sciences. McGraw-Hill, New York

Vlas, J. de (1979). Secondary production by tail regeneration in a tidal flat population of Lugworms (Arenicola marina), cropped by flatfish. Neth. J. Sea Res. 13: 362-393

This article was submitted to the editor; it was accepted for printing on July 30, 1987 